\title{
Typifications of Linnaean names Equisetum palustre (Equisetaceae) and Acrostichum punctatum (Polypodiaceae)
}

\author{
J. Mazumdar ${ }^{1}$, A. P. Shalimov $2^{*}$ \\ ${ }^{1}$ Department of Biological Sciences, Burdwan Town School, Burdwan-71301, West Bengal, India. \\ E-mail: jaideepmazumdar10@gmail.com \\ ${ }_{2}^{2}$ South-Siberian Botanical Garden, Altai State University, Lenina str., 61, Barnaul, 656049, Russia \\ *Corresponding author e-mail: man_biol@mail.ru
}

Key words: Acrostichum punctatum, Amman, China, Equisetaceae, Equisetum palustre, Linnaean name, Polypodiaceae, Russia.

Summary. In this paper, we propose types for Equisetum palustre (Equisetaceae) and Acrostichum punctatum (Polypodiaceae) described by C. Linnaeus in "Species Plantarum" (Linnaeus, 1753, 1763). Linnaeus obtained type specimens of Equisetum palustre from Johann Amman from Russia, who worked in St. Petersburg Academy of Sciences. But this type was actually Equisetum arvense and we selected Ray's (1724) illustration as lectotype and a specimen from Herbarium of South-Siberian Botanical Garden, Altai State University, Barnaul, Russia as an epitype. Type material of Acrostichum punctatum collected by the British physician and botanist J. Fothergill from Guangdong Province, China was absent in the LINN Herbarium or elsewhere and we selected a neotype from Herbarium of the Institute of Botany, Chinese Academy of Sciences (Beijing).

\section{Типификация названий Линнея Equisetum palustre (Equisetaceae) и Acrostichum punctatum (Polypodiaceae)}

\author{
Дж. Мазумдар ${ }^{1}$, А. П. Шалимов² \\ ${ }^{1}$ Факультет биологических наук, Бердуэн Таун Скул, Бурдван, 71301, Западная Бенгалия, Индия \\ ${ }^{2}$ Южно-Сибирский ботанический сад, Алтайский госуниверситет, пр-т Ленина, 61, Барнаул, 656049, Россия
}

Ключевые слова: Acrostichum punctatum, Амман, Китай, Equisetaceae, Equisetum palustre, названия Линнея, Polypodiaceae, Россия.

Аннотация. В статье обнародована типификация названий Equisetum palustre (Equisetaceae) и Acrostichum punctatum (Polypodiaceae), описанных К. Линнеем в «Species Plantarum» (Linnaeus, 1753, 1763). В связи с тем, что цитировавшийся Линнеем материал по Equisetum palustre, полученный из России, от профессора СанктПетербургской Академии наук Иоганна Аммана, относится к E. arvense, в качестве лектотипа выбрана иллюстрация Дж. Рэя (Ray, 1724), также прямо процитированная в протологе, а образец из гербария Южно-Сибирского ботанического сада Алтайского государственного университета, г. Барнаул, Россия (ALTB) обозначен как эпитип. Поскольку типовой материал по Acrostichum punctatum, собранный британским врачом и ботаником, Дж. Фозергиллом, в провинции Гуандун, Китай, отсутствует в LINN и в других гербариях, содержащих материал Линнея, в качестве неотипа выбран образец из гербария Института ботаники Китайской Академии наук, Пекин (РЕ). 
Here we typify two Linnaean names: Equisetum palustre L. (Equisetaceae) and Acrostichum punctatum L. (Polypodiaceae).

\section{Equisetum palustre}

Linnaeus (1753) proposed the name Equisetum palustre L. (Equisetaceae) in Species Plantarum citing provenance "Habitat in Europæ aquosis" indicating marshy region in Europe.

A specimen of E. palustre (Amman 60, Herb. Linn. No. 1241.5) in Linnaean Herbarium, London (LINN) carries Linnaeus' annotation "3 palustre", where 3 is the species number in Species Plantarum. Thus Linnaeus accepted LINN specimen as original material.

Linnaeus received this specimen from Johann Amman, Professor of Botany, St. Petersburg to whom he had correspondence and received some Russian specimens (Rowell, 1980; Jarvis, 2007). Thus Linnaeus' type locality in Europe for the name E. palustre is actually Russia from where Amman made collection (Rowell, 1980).

But Hauke (1966) carefully studied LINN specimen (LINN 1241.5) and found it to be E. arvense L., not E. palustre. Linnaeus had difficulty in distinguishing $E$. palustre from $E$. arvense. A specimen from Hortus Cliffortianus (BM 000647549) that Linnaeus (1753) cited in the protologue of E. arvense is actually E. palustre (Hauke, 1978).

No other Linnaean specimen of E. palustre was possible to locate. However, in the protologue of E. palustre Linnaeus (1753) cited "tab. 5 fig. 3" from Ray (1724) which is original material and we select it here as lectotype (Fig. 1). This illustration shows monomorphic aerial stem bearing cones. But it does not clearly exhibit number of teeth, relative length of sheath and first internode, depth of stem grooves, etc. essential to distinguish E. palustre from other species.

As Linnaeus' putative type locality is Russia, we select a Russian specimen from Herbarium of SouthSiberian Botanical Garden, Altai State University, Barnaul, Russia (ALTB) as epitype (Fig. 2).

\section{Typification}

Equisetum palustre L., 1753, Sp. P1. 2: 1061.

Lectotype (designated here): Ray, 1724, Syn. Meth. Stirp. Brit., ed. 3: 131, t. 5, f. 3 (Icon, Fig. 1).

Epitype (designated here): "[Russia]: Altai Republic, Ulagan district, south-east country side Aktash, right bank of Chuya, motley grass floodplain, meadow with exits of granite and loose rock of north-eastern macroslope. 1445 m. N 50¹5.059",

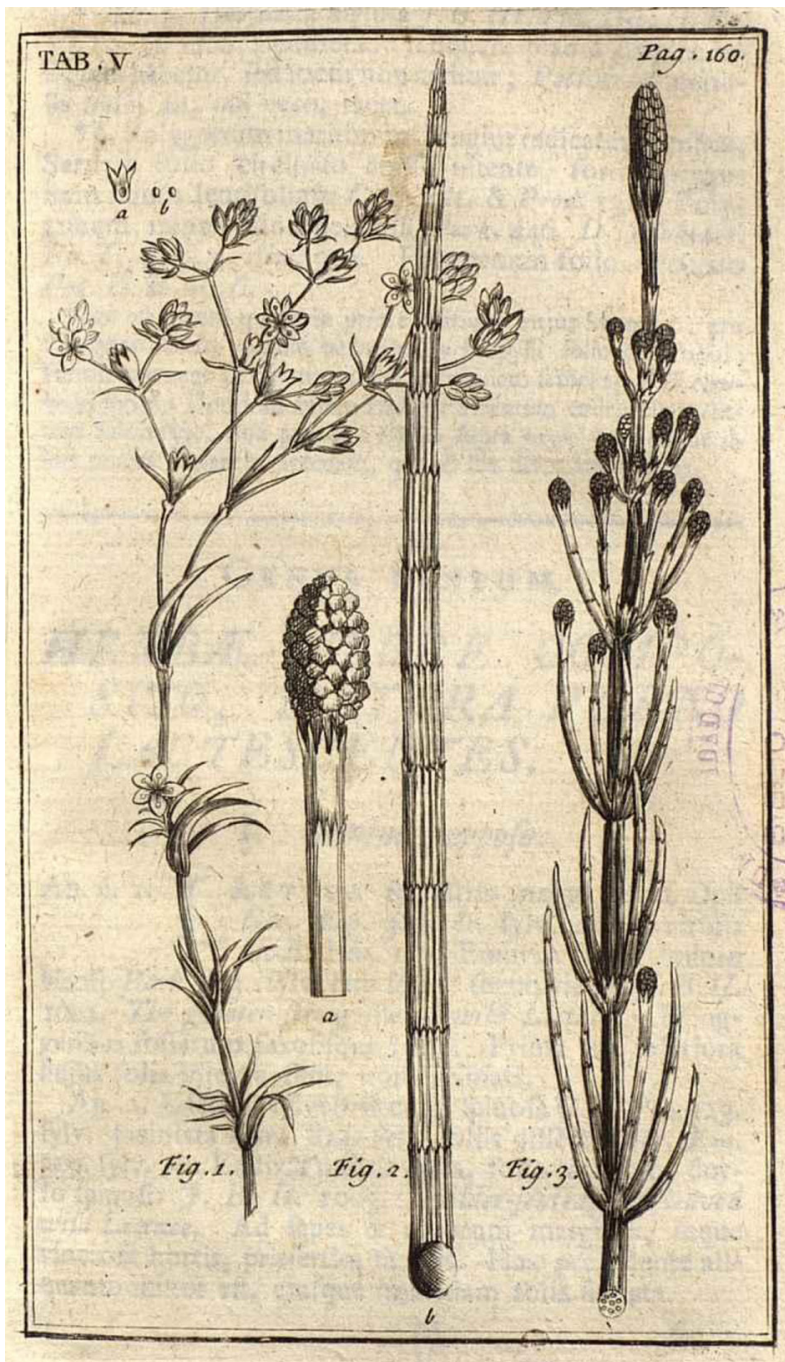

Fig. 1. Lectotype of Equisetum palustre L. (t. 5, f. 3. from Ray 1724).

E 87³9.205". 07 IIV 2015. A. P. Shalimov s. n." (ALTB, Fig. 2).

\section{Acrostichum punctatum}

In the protologue of Acrostichum punctatum L. Linnaeus (1763) only mentioned collection of John Fothergill from China which is obligate lectotype. But this specimen was not located (Bosman, 1991; Nooteboom, 1997; Jarvis, 2007). We select a specimen from the Herbarium of Institute of Botany, Chinese Academy of Sciences, Beijing (PE) as neotype (Fig. 3) from China.

\section{Typification}

Acrostichum punctatum L., 1763, Sp. Pl., ed. 2, 2: 1524. - Microsorum punctatum (L.) Copel., 1929, Univ. Calif. Publ. Bot. 16(2): 111.

Neotype (designated here): "China. Guangdong prov.: Tsingyun, on rocks by ravine. 9 June 1933, C. Wang 32560" (PE 00943781, Fig. 3). 


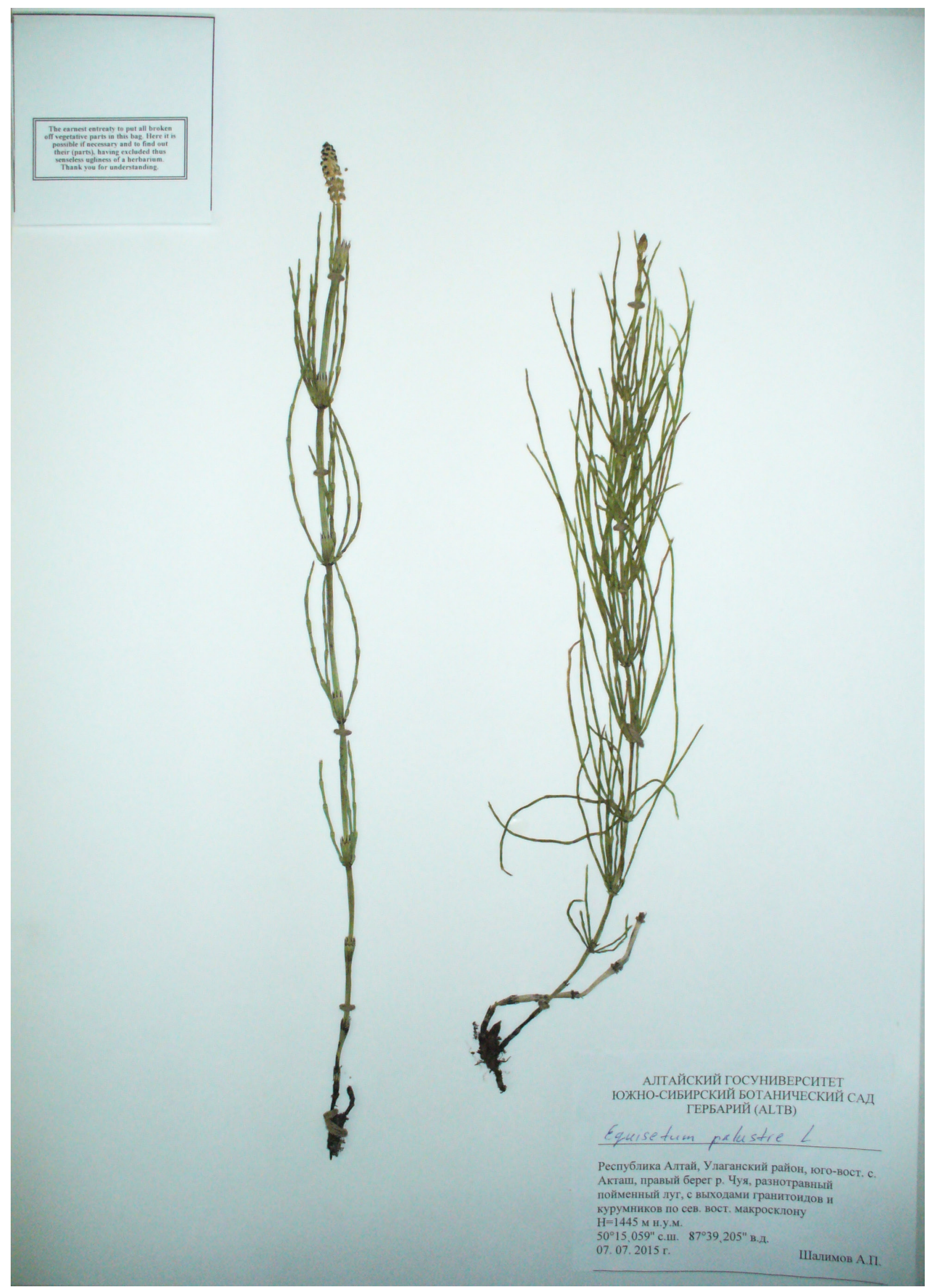

Fig. 2. Epitype of Equisetum palustre L. (Shalimov ALTB). Image courtesy Herbarium of South-Siberian Botanical Garden, Altai State University, Barnaul, Russia. 
Mazumdar J., Shalimov A. P. Typifications of Linnaean names Equisetum palustre and Acrostichum punctatum

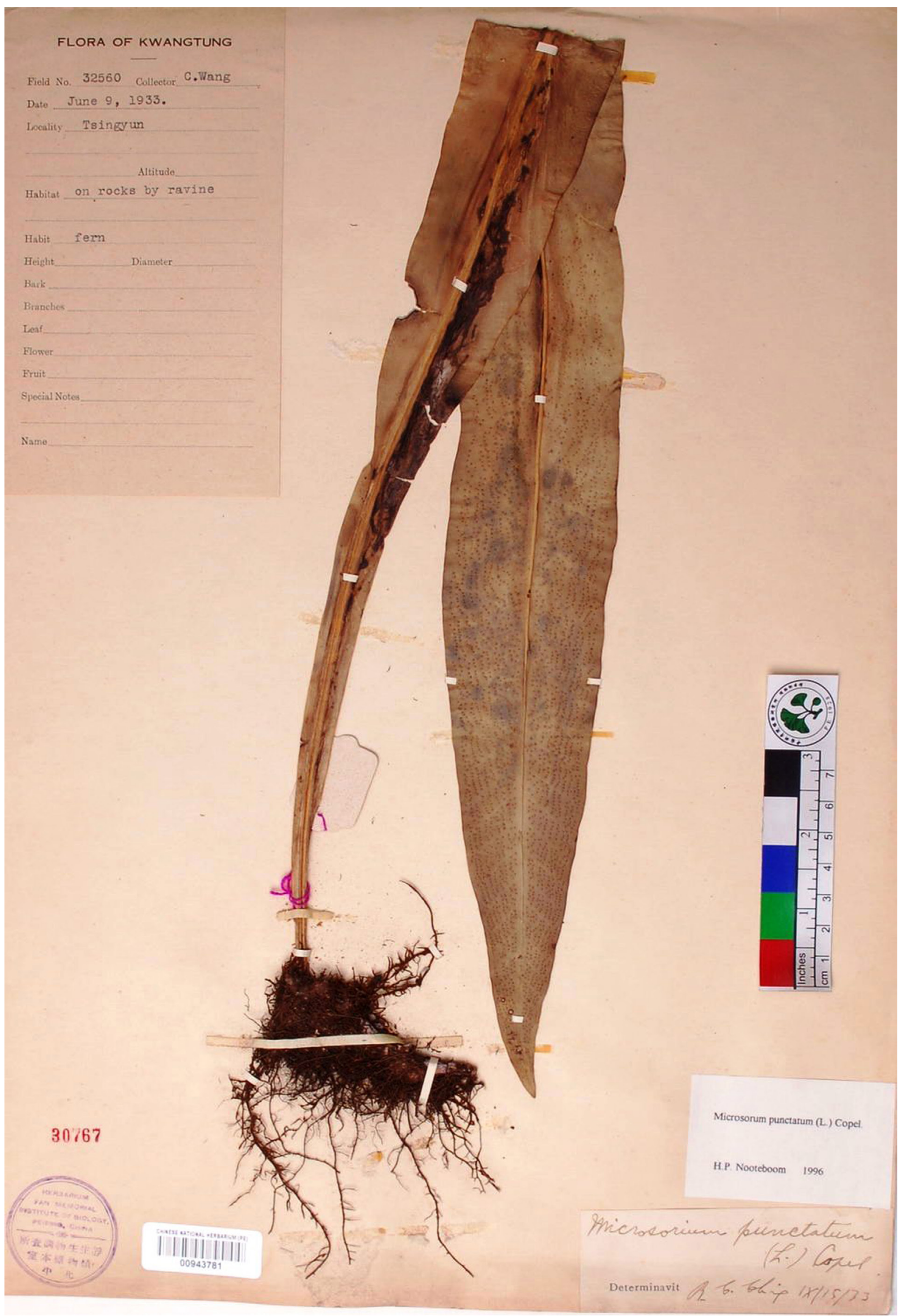

Fig. 3. Neotype of Acrostichum punctatum L. C. (Wang 32560, PE00943781). Image courtesy Herbarium of Institute of Botany, Chinese Academy of Sciences. Beijing, China. 
Acknowledgements. We sincerely thank Dr. J. McNeill, Royal Botanic Garden, Edinburgh (E) for invaluable advice and Dr. D. L. Des Marais, Harvard University, Cambridge, for helping with literature. We sincerely thank Prof. X. C. Zhang, Curator, Herbarium of Institute of Botany, Chinese Academy of Sciences (PE) and Prof. A. I. Shmakov, Director of South-Siberian Botanical Garden, and Dr. N. A. Usik, Curator, Herbarium of Altai State University, Barnaul (ALTB), for kind permission of publication of images of specimens. This work was supported by a grant from RFBR (15-34-51124 mol_nr).

\section{REFERENCES}

Bosman M. T. M. 1991. A monograph of the fern genus Microsorum (Polypodiaceae) including an attempt towards a reconstruction of the phylogenetic history of the microsoroids. Leiden Botanical Series 14: 1-161.

Hauke R. L. 1966. A systematic study of Equisetum arvense. Nova Hedwigia 13: 81-109.

Hauke R. L. 1978. A taxonomic monograph of Equisetum subgenus Equisetum. Nova Hedwigia 30: 385-455.

Jarvis C. 2007. Order out of chaos: Linnaean plant names and their types. Linnaean Society of London, London, $1016 \mathrm{pp}$.

Linnaeus C. 1753. Species Plantarum: exhibentes plantas rite cognitas, ad genera relatas, cum differentiis specificis, nominibus trivialibus, synonymis selectis, locis natalibus, secundum systema sexuale digestas. Vol. 2. Impensis Laurentii Salvii, Stockholm, 1200 pp.

Linnaeus C. 1763. Species Plantarum: exhibentes plantas rite cognitas, ad genera relatas, cum differentiis specificis, nominibus trivialibus, synonymis selectis, locis natalibus, secundum systema sexuale digestas. Vol. 2, Ed. 2. Holmiae: Impensis Direct. Laurentii Salvii, Stockholm, $1684 \mathrm{pp}$.

Nooteboom H. P. 1997. The microsoroid ferns (Polypodiaceae). Blumea 42(2): 261-395.

Ray J. 1724. Synopsis methodica stirpium britannicarum: Tum indigenis, tum in agris cultis locis suis dispositis; Additis generum characteristics, specierum descriptionibus \& virium epitome. Ed. 3. Impensis Gulielmi \& Joannis Innys Regiae Societatis Typographorum, in Area Occidentali D. Pauli, Londini, 482 pp.

Rowell M. 1980. Linnaeus and Botanists in Eighteenth-Century Russia. Taxon 29: 15-26. 